\title{
How China Could Win Over the Post-coronavirus World and Leave the US Behind
}

\begin{abstract}
As the US-China geopolitical contest gains momentum, the US has to ask itself if it can truly improve the lives of the people in the 191 remaining countries around the world.
\end{abstract}

To understand the post-Covid-19 world that is coming, there is one important human statistic we must bear in mind: 330 million people live in the US; 1.4 billion in China, and approximately 6 billion in the rest of the world. These 6 billion, who live in 191 countries, have begun preparing themselves for the US-China geopolitical contest. Their choices will determine who will win.

For most Americans, the contest is a no-brainer. Given a choice between a freedom-loving democratic US and an oppressive Communist China, the 6 billion would choose the US. Indeed many aspects of the US remain more appealing: great universities (for example, Harvard and Yale); Broadway, and Hollywood. Yet declining powers can also retain their cultural attractions. Witness the UK with Cambridge and Oxford, Shakespeare and Jane Austen.

The elites who run these 191 countries have been mostly educated in Westernstyle universities. They have learned to apply the cold calculus of reason to work out cost-benefit analyses of what both the US and China have to offer them. Sentiments won't play a role here. They have to decide at the end of the day which country, the US or China, will improve their citizens' living conditions.

Africa is a prime example. African leaders have studied East Asian economic success stories and learned from them. Trade, not aid, spurs economic growth. China is now the world's largest trading power; its total trade is USD 4.43 trillion compared to USD 3.89 trillion for the US To boost trade within Africa, first-rate infrastructure is needed. China is now the world's infrastructure superpower, building badly needed ports, railways, roads, and power stations in Africa. These projects include the megaport at Bagamoyo, Tanzaniya and the Addis Ababa-Djibouti Railway, which is the first fully-electrified cross-border railway in Africa. Paul Kagame, president of Rwanda, has said: "The Chinese bring what Africa needs: investment and money for

Originally published in MarketWatch, April 18, 2020 
governments and companies." Here's one leading indicator. When China convenes China-Africa summit meetings, all African leaders turn up.

It's commonly believed that China is sucking all these poor countries into a debt trap. A peer-reviewed academic study found this perception to be untrue. In a 2019 research paper, Johns Hopkins professor Deborah Brautigam concluded that most of these countries voluntarily signed on to these loans and had positive experiences working with China. Brautigam writes, "The evidence so far, including the Sri Lankan case, shows that the drumbeat of alarm about Chinese banks' funding of infrastructure across the BRI and beyond is overblown." She continues, “... a large number of people have favorable opinions of China as an economic model and consider China an attractive partner for their development.

For example, in 2014, 65\% in Kenya, 67\% in Ghana, and $85 \%$ in Africa's most populous country, Nigeria, held favorable views of China." Hence, when China launched its Belt and Road Initiative (BRI), to build infrastructure from Central Asia to Africa (and even to Latin America), most countries signed on. Yes, China has made mistakes with BRI. Mahathir bin Mohamad protested against its terms when he became Prime Minister of Malaysia in 2018. However the deal was quietly renegotiated, and Mahathir became one of the key opening speakers of the BRI Summit in Beijing in 2019.

Italy is another leading indicator of how the world is turning. It's a member of the G-7, the core group of the Western club. Its economy is ailing. China has stepped up to offer new investment in Italy. Former Italian Minister of Economy and Finance Giovanni Tria has called Chinese investments "a circle virtuous, satisfying and diffuse growth" and referred to them as "a train that Italy cannot afford to miss." Now, Covid19 has given China-Italy relations a major boost. While its fellow EU members initially balked at helping Italy, China responded almost immediately, sending 31 tons of much-needed medical equipment, pulmonary ventilators, face masks, and protective suits.

In previous disasters, such as the 2004 Boxing Day Tsunami that hit Indonesia, the US was the first to arrive with aid. China offered little. With Covid-19, the roles have reversed. The 6 billion people outside the US and China are genuinely shocked to see the sharp contrast between the competent responses of China and the incompetent responses of the US They would agree with the assessment of the World Health Organization: "China's bold approach to contain the rapid spread of this new respiratory pathogen has changed the course of a rapidly escalating and deadly epidemic".

Equally importantly, a leading Western medical journal, The Lancet, published an open letter from leading medical and public health professionals also praising China's response, noting that efforts made by "scientists, public health professionals, and medical professionals of China... [were] remarkable."

\section{Winning friends and influencing people}

Yet all of this doesn't mean that the vast majority of countries will abandon the US and join China's camp. Far from it. Most countries want to maintain good ties with both powers, they just don't want to be forced to choose. If China offers good and cheap 
5G technology from Huawei, for example, most countries (including US allies such as the UK, Germany and France) want the freedom to choose the best technology or their telecommunications infrastructure. So when the US imposes sanctions on countries buying from Huawei, it's causing problems with friends.

Freedom to choose what is best for one's own country is a demand that many friends of the US are calling for. India and Turkey want to be free to choose S-400 missiles from Russia; Indonesia wants to buy Sukhoi jet fighters. Similarly, the UK, France and Germany want the freedom to trade with Iran through INSTEX, a special clearing mechanism they set up to facilitate trade with Iran.

The US can still recover a lot of influence it enjoyed in the world. Vast reservoirs of goodwill toward the US remain, for example, among the 10 ASEAN nations of Southeast Asia. Indeed, two of them, Philippines and Thailand, are "technically" treaty allies with the US. Yet there is no doubt that both of these countries are now closer to China than to the US. All 10 ASEAN countries do more trade with China than with the US. To balance this, the stock of US investment in ASEAN countries is far greater. Indeed, America's total investment in ASEAN of USD 328 billion is far more than what it has invested in India, China, Japan and Korea combined. By contrast, the Chinese investment in ASEAN is about USD 150 billion.

The 10 ASEAN countries, like the 181 other countries, don't want to be caught in a zero-sum geopolitical contest between the US and China. Quite reasonably, they want to keep their options open. With skillful diplomacy, the US can still win the game. Sadly, the art of diplomacy has been lost in Washington DC This has created a massive opening that China has taken full advantage of, on its way to victory over the post-Covid-19 world.

\footnotetext{
Open Access This chapter is licensed under the terms of the Creative Commons AttributionNonCommercial-NoDerivatives 4.0 International License (http://creativecommons.org/licenses/bync-nd/4.0/), which permits any noncommercial use, sharing, distribution and reproduction in any medium or format, as long as you give appropriate credit to the original author(s) and the source, provide a link to the Creative Commons license and indicate if you modified the licensed material. You do not have permission under this license to share adapted material derived from this chapter or parts of it.

The images or other third party material in this chapter are included in the chapter's Creative Commons license, unless indicated otherwise in a credit line to the material. If material is not included in the chapter's Creative Commons license and your intended use is not permitted by statutory regulation or exceeds the permitted use, you will need to obtain permission directly from the copyright holder.
}

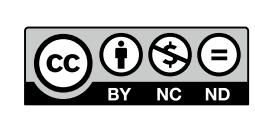

